\title{
Microstamping - Does it Really Help?
}

\author{
B.A. Neil* \\ Retired Professor, Business Law \\ *Corresponding Author: B.A. Neil, Retired Professor, Business Law

\begin{abstract}
This case problem provides a test of a student's basic knowledge of the California statute regarding microstamping of semi-automatic handguns. The case introduces the student to the basic problems engaged by law enforcement when attempting to solve a crime. It also highlights the problems and potential pitfalls for normal citizens. Who may be innocently caught up in a criminal investigation.
\end{abstract} \\ The case is suited for students taking their first criminal law exercise or course. After reading and discussing \\ the case, students should have a pragmatic understanding of what occurs in a criminal investigation, before \\ ever going to a trial. \\ The following fact pattern is based on the application of the California statute regarding micro-stamping of \\ semi-automatic handguns.
}

Keywords: Microstamping, semi-automatic handgun, revolver, firing pin, robbery and murder.

\section{PREMise}

The victim, Steve Baxter, had just finished coaching his church basketball team, located in East L.A., California. For years, he had been volunteering his time and talents to both the boys and girls of his church. Having played professional basketball in Europe. He was a big man but very friendly and approachable. Spending his spare time mentoring and counseling any child who would approach him for help. As he knew that many of the kids came from one parent or broken homes. He did his best to help, whenever he could. Even buying shoes for players, whose family couldn't afford them, but not telling the rest of the team.

After practice on one particularly hot day, he decided to stop by a convenience store on the way home and get a cool drink, since it was summertime and quite hot playing and practicing basketball on the blacktop court. Steve parked out front of the store, since it wasn't the best of neighborhoods and it was starting to get dark. He went inside and purchased a Gatorade drink and proceeded to leave the store and return to his car.

That's when Anthony Jones approached him with an unknown accomplice. Both of them were dressed in black and had hoodies pulled over their heads. Anthony told Steve to "kick it out" apparently meaning for Steve to give him his wallet. However, Steve refused. That's when Anthony produced a handgun, and forcibly took Steve's wallet and cell phone. But before leaving the scene, Anthony shot Steve in the chest three times. Apparently killing him instantly according to the subsequent coroner's report.

The store clerk was In the back of the store at the time of the shooting re-stocking shelves and did not see the robbery and murder. But he did hear the shots. He ran outside, however, Steve was already dead according to his statement later to the police and Anthony and his accomplice were long gone.

The police tried to get a copy of the video from the store, but the entire taping system was down and not functioning that night... In addition, there were no shell casings at the scene to be collected and subsequently analyzed by the police.

Several nights later, the police arrested an individual on a minor drug offense. At that time, he offered to provide the police with information regarding the name and address of the shooter from the convenience store shooting for several nights prior. This was to be in return for a "deal", wherein the charges against him would be dropped. 
The police agreed and based on his information, they got a search and seizure warrant for the residence of one Anthony Jones. While executing the warrant, the police were able to recover a five (5) shot revolver, some cash and two (2) ounces of marijuana. Immediately. Anthony invoked his $5^{\text {th }}$ Amendment privilege. Where upon, he was arrested without incident.

\section{QUESTIONS}

1) Will Anthony be convicted of a crime, based on these facts alone?

2) Does microstamping allow police to connect the firearm to the registered owner?

3) If microstamping allows the police to track down guns, what are the inherent disadvantages?

4) Is the cost of microstamping insignificant? And if so, are there any exemptions to the California statute?

5) Have other states considered a similar statute?

6) What other legal/ political or practical issues are in play regarding this fact scenario?

\section{TEACHING NoteS}

1) Will Anthony be convicted of a crime, based on these facts alone?

Probably only simple possession of an illegal drug. There is nothing else to connect Anthony with the crime. If however, he is a felon in possession of a handgun, he may be charged with that. Otherwise, it is not illegal to have a handgun in your personal residence.

\section{2) Does microstamping allow police to connect the firearm to the registered owner?}

The process will permit police departments to match used cartridge casings from potential crime scenes to the registered owner of the gun. However, the process only allows the police to connect the gun with the registered owner. Many handguns are stolen or sold on the black market. It does not make any connection to the person or persons who used the gun at the crime scene.

\section{3) If microstamping allows police to track down guns, what are the inherent disadvantages?}

If someone had a criminal mind, they could collect used shell casings at a legal firing range and then later place them at a crime scene. Thereby placing innocent persons in harm's way of a criminal investigation.

For one, the California statute does not apply to revolvers. (Since they do not eject spent casings.) Only semi-automatic handguns and only the current models. Older models are "grandfathered" in. In addition, it is entirely possible to replace the firing pin in the handgun, which would defeat any attempt to "track" the handgun.

4) Is the cost of microstamping insignificant? And if so, are there any exemptions to the California statute?

Gun manufacturers state that the cost of producing the semi-automatic firearms with the required statutory technique would potentially be significant. And would necessarily be passed on to the legitimate buyers. Thereby increasing the cost of such guns.

\section{5) Have other states considered a similar statute?}

Other states considering similar statutes are Illinois, New York, Maryland, Massachusetts, Rhode Island and Wisconsin.

\section{6) What other legal/ political or practical issues are in play regarding this fact scenario?}

This question should lead to an open and lively discussion concerning the facts as listed in this hypothetical case problem. The instructor should be prepared for the students to go "off script" when discussing various aspects of this case. Thus, encouraging an open and frank droup discussion.

Citation: B.A. Neil. "Microstamping - Does it Really Help?" International Journal of Humanities Social Sciences and Education (IJHSSE), vol 4, no. 12, 2017, pp. 46-47. doi: http://dx.doi.org/10.20431/23490381.0412005 .

Copyright: (C) 2017 Authors. This is an open-access article distributed under the terms of the Creative Commons Attribution License, which permits unrestricted use, distribution, and reproduction in any medium, provided the original author and source are credited. 